\title{
Spatio-temporal characteristics of the mainland coastline utilization degree over the last 70 years in China
}

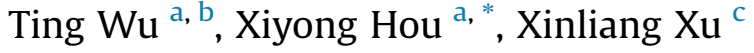 \\ a Yantai Institute of Coastal Zone Research (YIC), Chinese Academy of Sciences (CAS), 264003 Yantai, China \\ ${ }^{\mathrm{b}}$ University of the Chinese Academy of Sciences, 10049 Beijing, China \\ ${ }^{\mathrm{c}}$ Institute of Geographic Sciences and Natural Resources Research (IGSNRR), Chinese Academy of Sciences (CAS), 100101 Beijing, China
}

\section{A R T I C L E I N F O}

\section{Article history:}

Available online

\begin{abstract}
A B S T R A C T
Based on topographic maps and remote sensing imageries measured or captured at time instants varied from 1940s to 2012, mainland coastline in 1940s, 1960s, 1990, 2000, 2010 and 2012 in China were delineated and classified into eight types according to the differences in anthropogenic utilization. And the index of coastline utilization degree (ICUD) was defined and calculated for mainland coastline at national, provincial and local scales respectively. It turned out that, 1 ) over the last 70 years, especially during the last two decades in China, the ICUD increased continuously and dramatically, which shows that the impacts of human beings on mainland coastline increased incessantly. 2) Significant spatial patterns and temporal variations of the ICUD could be observed, in specific, the Yangtze River delta had much higher ICUD in the early stages; however the ICUD in the Pearl River delta and Circum Bohai Bay increased more dramatically than the Yangtze River delta in the last two decades. 3) At national and provincial scales, the intensive and accelerated exploitation of coastline, following the continual decrease of natural coastline over the last 70 years had determined the temporal trends of ICUD. However, the spatio-temporal patterns of ICUD exhibited much complicated characteristics at local scale because both human activities and physical factors had significant impacts on coastline changes. 4) Overall, the ICUD effectively revealed the spatio-temporal characteristics of mainland coastline changes and impacts of human activities on coastline in China. It will be helpful for China's ICZM decision makings to monitor the mainland coastline changes and analyze its dynamics by ICUD.
\end{abstract}

() 2014 Elsevier Ltd. All rights reserved.

\section{Introduction}

Coastal zone refers to the interface of land and sea, housing approximate 60 percent of the world population and two thirds of major cities with a population exceeding 1.6 million(Privmavera, 2006), therefore, being distinct from other physical geographical systems, it is affected by the land processes (e.g., changes of rain fall and runoff (Ranasinghe et al., 2013), and tectogenesis (Vora, 1987)), oceanic processes (e.g., wave (Szmytkiewicz et al., 2000), tide (Stockdon et al., 2007), storm (List et al., 2006), sea level change (Leatherman, 1990)) and anthropogenic activities (e.g., sand mining (Romine and Fletcher, 2013), sand nourishment (Foyle and Norton, 2006), coastal project (Li et al., 2001) and land reclamation (Sesli et al., 2009)) simultaneously, which make it an ecosystem with

\footnotetext{
* Corresponding author. ChunHui Road 17\#, Laishan District, Yantai 264003, Shandong, PR China. Tel.: +860535 2109196.

E-mail addresses: twu@yic.ac.cn (T.Wu),xyhou@yic.ac.cn (X. Hou), xuxl@lreis. ac.cn (X. Xu).
}

the most significant sensitivity and volatility. As the interface of land and sea, the spatial fluctuation and property changes of coastline reflect the alternation of coastal advancement and erosion, as well as the spatio-temporal variability of coastline utilization, hence, the study on coastline changes has become the most general and effective approach to characterize the variations of coastal environment. Since the twentieth century, with the anthropogenic living space advancing seaward gradually, the effects of anthropogenic activities on the coastal environment have surpassed that of natural forces, becoming the prevailing factors that arouse more rapid and drastic coastline changes (Aiello et al., 2013; Sridhar et al., 2009; Yildırım et al., 2010). China had experienced four booms in sea reclamation since the founding of new China, and by the end of the last century, the reclaimed area had amounted to $12000 \mathrm{~km}^{2}$. For the last two decades, the reclamation in China expanded dramatically in a speed that many times before. Artificialization occurred everywhere except some parts near the estuaries, and at present, artificial coastline has occupied more than half of the mainland coastline, especially in Bohai Bay. Human 
activities affect the mould process of coastline figuration, and in reverse, are driven by coastline changes (McNamara et al., 2011), as both the loss of natural coastline and properties changes of coastline have significant influence on human activities (Sridhar et al., 2009). Effective monitoring and analysis of the coastline changes is crucial to reasonable littoral exploitation, utilization and protection (Crowell et al., 2010).

Researchers around the world conducted their studies on coastline changes chiefly from two perspectives: 1) Calculating coastline change rates and change areas of land or sea to characterize spatio-temporal variability of coastline (Ahmad and Lakhan, 2012; Dolan et al., 1978; Kuleli, 2010; Kuleli et al., 2011; Kusimi and Dika, 2012; Yates et al., 2013). 2) Exploring the effects of geology, geomorphology, climate and economy on coastline changes based on analysis of spatio-temporal patterns of coastline changes (Durduran, 2010; Quan et al., 2013; Solomon, 2005; Twichell et al., 2013). However, study on long-term characteristics of coastline changes at national scale is rare. In this paper, based on datasets of mainland coastline extracted from topographic maps and remote sensing imageries, we revealed spatio-temporal features of mainland coastline changes affected by human activities in China over the last 70 years by building the index of coastline utilization degree.

\section{Data and methodology}

\subsection{Data source}

The data used include: 1) 48 topographic maps at scale of 1: 250000 covering the coastal area of Mainland China, most of which were mapped during the period of 1940-1945 by the Army Map Service (LU), Corps of Engineers, U.S. Army; 2) 275 and 39 topographic maps of the coastal zone in China at scale of 1:50 000 and 1:100 000 respectively, most of which were mapped during the time span of 1955-1965; 3) Landsat TM/ETM + imageries with a spatial resolution of $30 \mathrm{~m}$ captured in 1990, 2000 and 2010, all of which had undergone radiometric, geometric, and topographic correction, and were downloaded freely from EROS (Earth Resources Observation and Science Center) website (http://glovis.usgs.gov/); 4) CCD imageries with a spatial resolution of $30 \mathrm{~m}$ that were captured by the Chinese Environment and Disaster Monitoring Small Satellite in 2012, and downloaded freely from China Centre for Resources Satellite Data and Application website (http://www.cresda.com).

\subsection{Extraction and classification of mainland coastline}

Extraction and classification of mainland coastline were fulfilled based on knowledge acquired from both field surveys and visual interpretation. During the period of 2011-2013, we conducted ten field surveys that covered the whole coastal zone in China, and after a 16.3 thousand kilometers' journey with 39 person-time, we finally got more than 7 thousand site photos, collected 578 control points using GPS receiver, and established technical manuals for field identification and screen-based interpretation for different kinds of coastlines (Table 1). Ultimately, datasets of mainland coastline in 1940s, 1960s, 1990, 2000, 2010 and 2012 were created and classified by digitizing the topographic maps and visually interpreting the remote sensing imageries.

\subsubsection{Index of coastline utilization degree}

The index of coastline utilization degree (ICUD) was defined through referring to the conception and computational method of land utilization degree (Zhuang and Liu, 1997). In specific, according to field survey experience about the differences in human impacts on various coastline, we assigned distinct scores of human force degree to each kind of coastline utilization (Table 2). Impact degree of human activities on coastline and difficulty of reverting coastline to natural state increased, while the functional diversity of coastline declined, with the index of human force degree ranging from 1 to 4 .

The index of coastline utilization degree could be calculated through Equation (1):

$$
\operatorname{ICUD}=\sum_{i=1}^{n}\left(A_{i} \times C_{i}\right) * 100
$$

where, ICUD is the index of coastline utilization degree, $A_{i}$ is the score of human force degree of category $i$ utilization, $C_{i}$ is the coastline length percentage of category $i$ utilization, $n$ is the number of coastline utilization situations.

An increase in ICUD indicates an enhancement of human impacts on coastline, which involves many situations, such as to build a seawall on a natural beach or on the landward side of muddy tidal flat in order to prevent shore from erosion, and to convert salt pans into harbors driven by the adjustment of coastal industrial structure. By contrary, a decrease in ICUD implies coastline movement accompanied by utilization changes, such as coastline recession from seawalls to locations where land has not been exploited yet due to extreme storm surges, and coastline advancement from seawalls to muddy coastline that is newly formed through sea reclamation for the purpose of aquaculture. Also, land expansion and seaward movement of coastline or emerging of new natural coastline because of coastal siltation processes will lead to declines of ICUD.

Table 1

Utilization categories and interpretation rules of mainland coastline in China.

\begin{tabular}{|c|c|c|}
\hline Categories & Introduction & Extraction rules based on maps and imageries \\
\hline Groin and Jetty & $\begin{array}{l}\text { Groin: low wall built out into the sea obliquely to prevent it from } \\
\text { washing away sand and stones from beaches and regulate along } \\
\text { shore current; Jetty: a wall built out into the sea with one side } \\
\text { on shore for wave defending }\end{array}$ & $\begin{array}{l}\text { Its geometric morphology is prone to be identified, generally, } \\
\text { consider it as a single line feature due to its limited width and take } \\
\text { its central line as the shoreline proxy, but as to the wide one, take } \\
\text { the seaward edge }\end{array}$ \\
\hline Harbor and Wharf & Seaward side of harbor and wharf & $\begin{array}{l}\text { Its geometric morphology is prone to be identified, generally, take } \\
\text { the seaward edge as the shoreline proxy }\end{array}$ \\
\hline Reclamation & Seaward side of the districts that are being reclaimed & The same as above \\
\hline Aquaculture Dike & Seaward side of the aquaculture ponds & The same as above \\
\hline Salt Pan Dike & Seaward side of the salt pans & The same as above \\
\hline Embankment & A raised structure used to hold back water, as well as to carry a roadway & The same as above \\
\hline Sea Wall & Other coastal protection projects that separate land from water & The same as above \\
\hline Natural Coastline & Coastline that hasn't been utilized & $\begin{array}{l}\text { 1) rocky coast: its geometric morphology is prone to be identified, } \\
\text { generally, take the bluff foot line as the shoreline proxy; } 2 \text { ) sand and } \\
\text { shingle beach: with scarp, take the scarp foot line, or else, take the } \\
\text { beach crest line }\end{array}$ \\
\hline
\end{tabular}


Table 2

Indices of human force degree for all utilization situations of coastline.

\begin{tabular}{|c|c|c|c|c|c|c|c|c|}
\hline Utilization & Groin and Jetty & Harbor and Wharf & Embankment & Reclamation & Aquaculture dike & Salt pan dike & Seawall & Natural coastline \\
\hline Index & 4 & 4 & 4 & 4 & 3 & 3 & 2 & 1 \\
\hline
\end{tabular}

2.2.2. Scales to calculate the index of coastline utilization degree

The index of coastline utilization degree was calculated at national, provincial and local scales respectively (Fig. 1). The local scale referred to the basic space cells that produced by dividing the whole coastal zone in China into subunits, specifically, to buffer each of the six coastlines at a radium of $5 \mathrm{~km}$ at first, and then to merge the six buffer zones into a single polygon that covered all the six coastlines, next, to cast transects perpendicularly to the seaward edge of this merged polygon at a space of $50 \mathrm{~km}$ and then to adjust the transects that self-intersected or crossed one coastline twice (Jackson Jr. et al., 2012); ultimately, in this study, 135 basic space cells were obtained and numbered from north to south.

\section{Results}

3.1. Spatio-temporal dynamics of mainland coastline utilization degree at national scale

As shown in Fig. 2, over the last seventy years, proportions of groin and jetty, harbor and wharf, reclamation, and aquaculture dike showed a continuously increasing trend, whilst proportions of salt pan dike and sea wall had a overall declining trend with fluctuations and peaked at the year of 2000; comparison of coastline structure in 1940s and in 2012 presented that: the proportion of embankment increased overall during the whole studied period, but declined during the periods of 1940s-1960s and 2010-2012; the proportion of natural coastline continuously decreased during the whole studied period. ICUD had increased by 117.72 with an annual average of 1.68 , exhibiting not only a continuously increasing trend but also a remarkable phased characteristic: during the periods of 1940s-1960s and 1960s-1990, it increased with similar annual average rates smaller than 0.6; during the periods of 1990-2000 and 2000-2010, it increased with rates that were almost ten times and six times the preceding phase, respectively; during the period of 2010-2012, the rate slowed down but was still many times the first stage. The phased characteristics indicated that, natural coastline experienced the most remarkable decline whilst the ICUD showed the most notable increase during the period of 1990-2000, due to coastline hardening mainly caused by the construction of embankments, harbor and wharf; however, although the declining trend of natural coastline had obviously slowed down, the increasing rate of ICUD maintained in a high level mainly due to the mutual transitions among different kinds of coastline utilizations since 2000.

\subsection{Spatio-temporal dynamics of mainland coastline utilization degree at provincial scale}

As illustrated in Fig. 3, over the nearly seventy years, coastline utilization degrees of Tianjin city, Liaoning province, Shandong province, Fujian province, and Guangdong province showed a continuously increasing trend. Among these five regions: Tianjin

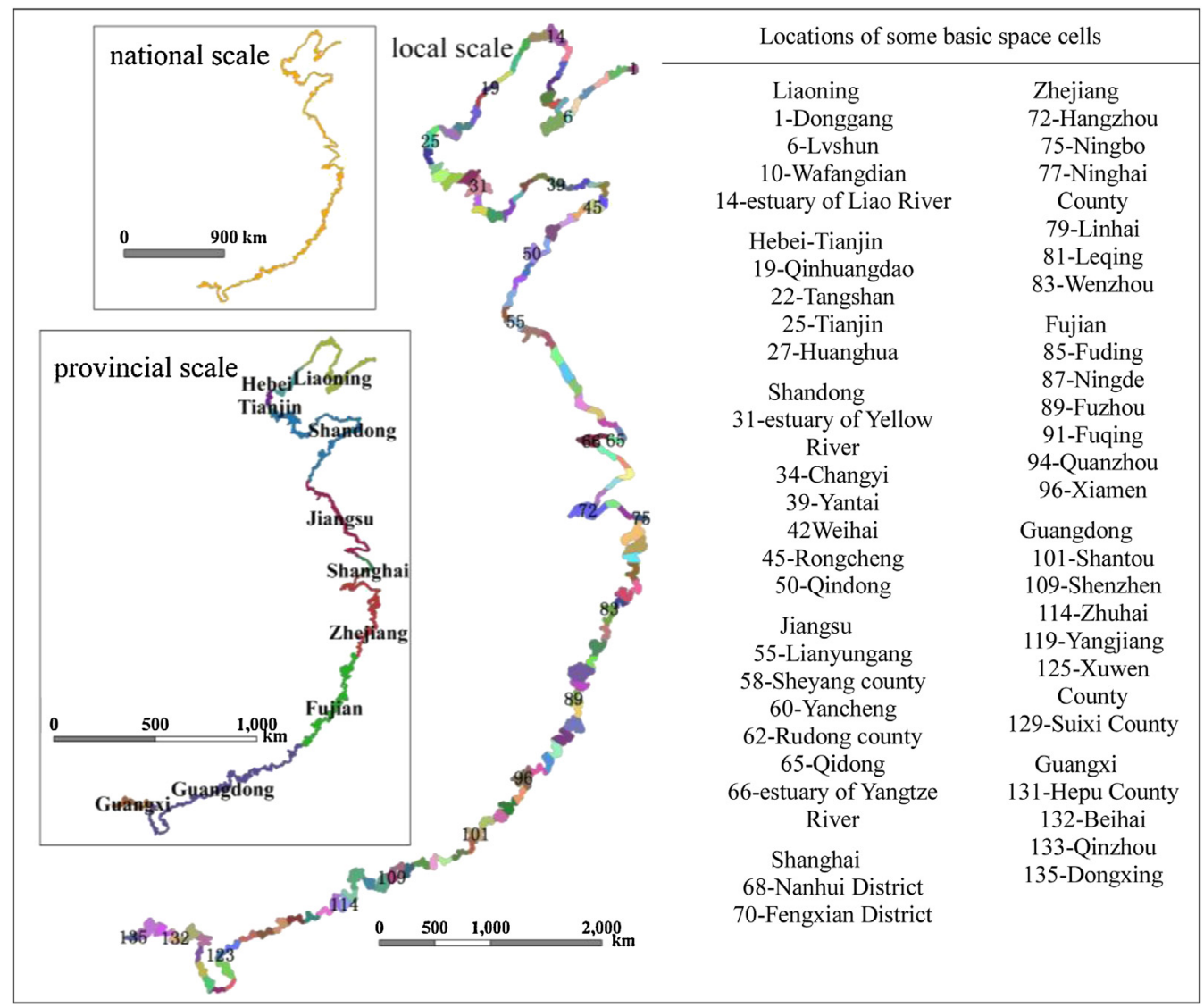

Fig. 1. Scales at which coastline utilization degree were calculated. 


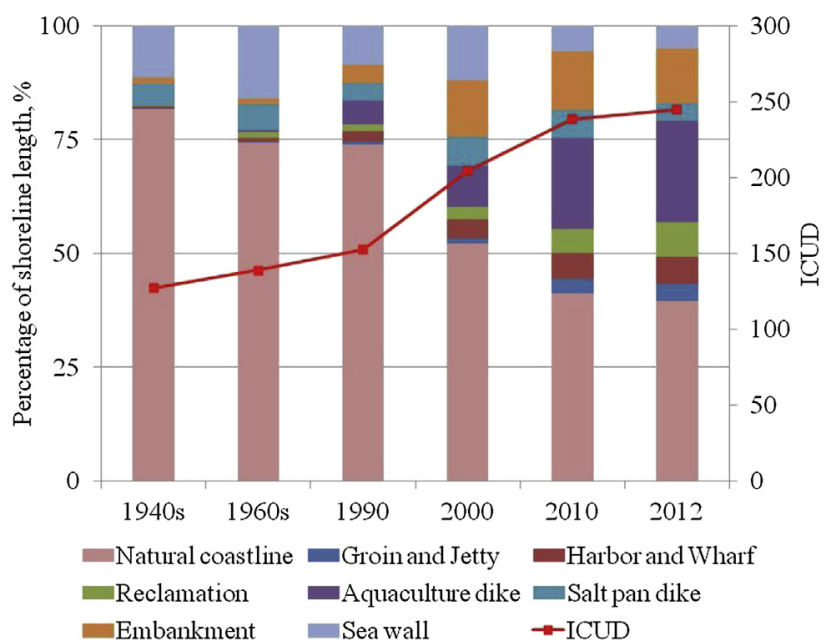

Fig. 2. Structural characters and ICUD of China's mainland coastline in different phases.

city had been undergoing the most extensively reclamation and harbor construction since the founding of new China, furthermore, it had superseded Shanghai city and become the coastal zone with the highest coastline utilization degree since 1990; Liaoning province had a strong momentum in economic development since 1990 owing to the rapid expansion of aquaculture and salt industry and the boom of harbor construction, thereby superseding Shanghai city after 2010 and becoming the coastal zone with the third highest coastline utilization degree. During the period of 1940s-1960s, coastline utilization degree of Guangxi Zhuang Autonomous Region decreased mainly due to the proportion reduction of sea wall induced by the damage of storms or human activities.

As the southern coastal zone was mainly mountainous region, the changes of coastline utilization degree in Zhejiang province mainly occurred in Hangzhou Bay. During the period of 1940s-1960s, the coastline utilization degree of Zhejiang province increased; coast accretion and damage of seawalls caused by emergent events on southern coast of Hangzhou bay, in addition to discard of salt pan on northern coast, over the time span from the mid-1980s to the end of last century, resulted in a decline of coastline utilization degree in Zhejiang province during the period of 1960s-1990; however, the coastline utilization degree of Zhejiang province sustained the rising tendency since 1990 due to the reclamation, mudflat aquaculture and seawall construction on the southern coast of Hangzhou bay since 1986 (Wang et al., 2011).

In Shanghai city, incessantly sea reclamation was documented over the nearly 70 years (Sun et al., 2011). Sea reclamations in

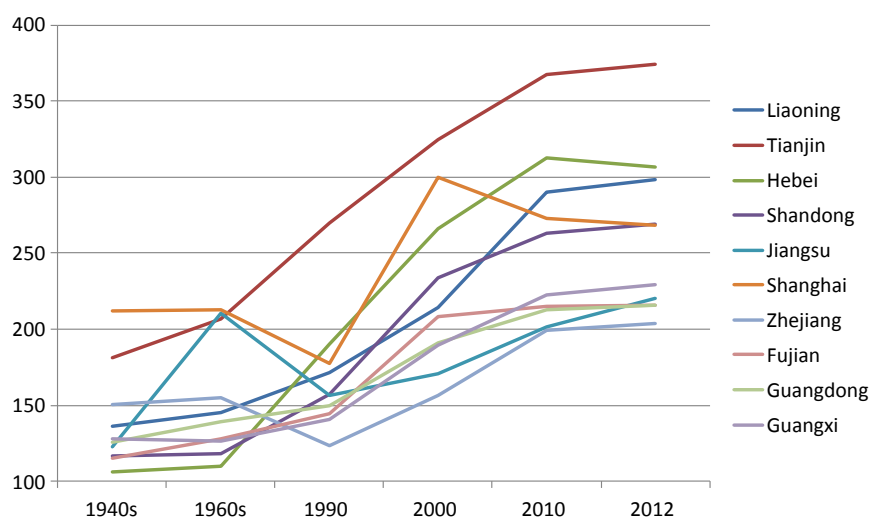

Fig. 3. Temporal variations of ICUD at provincial scale.
Shanghai city were mainly for urban construction and agriculture, but on the southern coast of the Yangtze River estuary where accretion never suspended, seawalls had to be built on the seaward edge in order to protect the city and croplands or to facilitate siltation, consequently, artificial coastline and natural coastline alternate both in geographic space and over time (Sun et al., 2010), leading to fluctuations and irregular changes of coastline utilization degree.

At the beginning of new China, seawalls were constructed extensively for revetment in Jiangsu province (Zhang et al., 2012), hence, during the period of 1940s-1960s, the proportion of seawall had a significant increase which resulted in a sharp rise in the coastline utilization degree; thereafter, till the mid-1990s, a large area of wetlands appeared on the seaward side of the seawalls due to natural accretion and artificial construction, as a result, the proportion of seawall decreased notably and the coastline utilization degree reversed sharply; however, mainly driven by the economic interests, economic interest-oriented reed wetlands and aquaculture increased substantially (Suo et al., 2012), therefore, since the late 1990s, the coastline utilization degree of Jiangsu exhibited a continuously rising trend.

The coastline utilization degree increased most significantly in Hebei province. The sea reclamation project of Caofeidian district, started in 2003, was projected to fulfill a reclamation of 310 square kilometers by the end of 2030, and 105 square kilometers had been finished by the end of 2010 (Suo et al., 2012), thereby making the coastline utilization degree of Hebei province surpass Shanghai city and rank the second among the coastal provinces in 2010; a certain area of reclamation land that was completed before 2010 was used for aquaculture after 2010, which caused a rise in the proportion of aquaculture and a reduction in the proportion of reclamation, and accordingly, produced a mild decrease in the coastline utilization degree during the period of 2010-2012.

\subsection{Spatio-temporal dynamics of mainland coastline utilization degree at local scale}

The index of coastline utilization degree was calculated for 135 space cells at six epochs (Fig. 4), and then the frequency distribution was plotted (Fig. 5).

\subsubsection{Overall characteristics of spatio-temporal dynamics of mainland coastline utilization degree}

Spatio-temporal dynamics of mainland coastline utilization degree at local scale over the nearly 70 years are as follows:

1) there is a remarkable gap of mainland coastline utilization degree between south and north diverged within a zone that covered the coastal area of Qidong, the Yangtze River estuary and Hangzhou bay: as illustrated in Fig. 4, the coastline utilization degree of south was generally higher than that of north before 1990, but after 1990, it reversed;

2 ) the coastline utilization degree had undergone an generally incessant and accelerated rise from north to south since the 1940s: as illustrated in Fig. 5, the frequency of low values had a dramatic decrease while that of high values had a remarkable increase, presenting a typical shift from low values to high values, specifically, a big jump from 1990 to 2000.

\subsubsection{Spatial patterns of mainland coastline utilization degree at different times}

In 1940 s, $23.70 \%$ of the total cells, carried the value of 100 , meaning the whole coastline within these zones remained natural by 1940 s; 7 cells, carried values greater than 200 , that is to say, their 

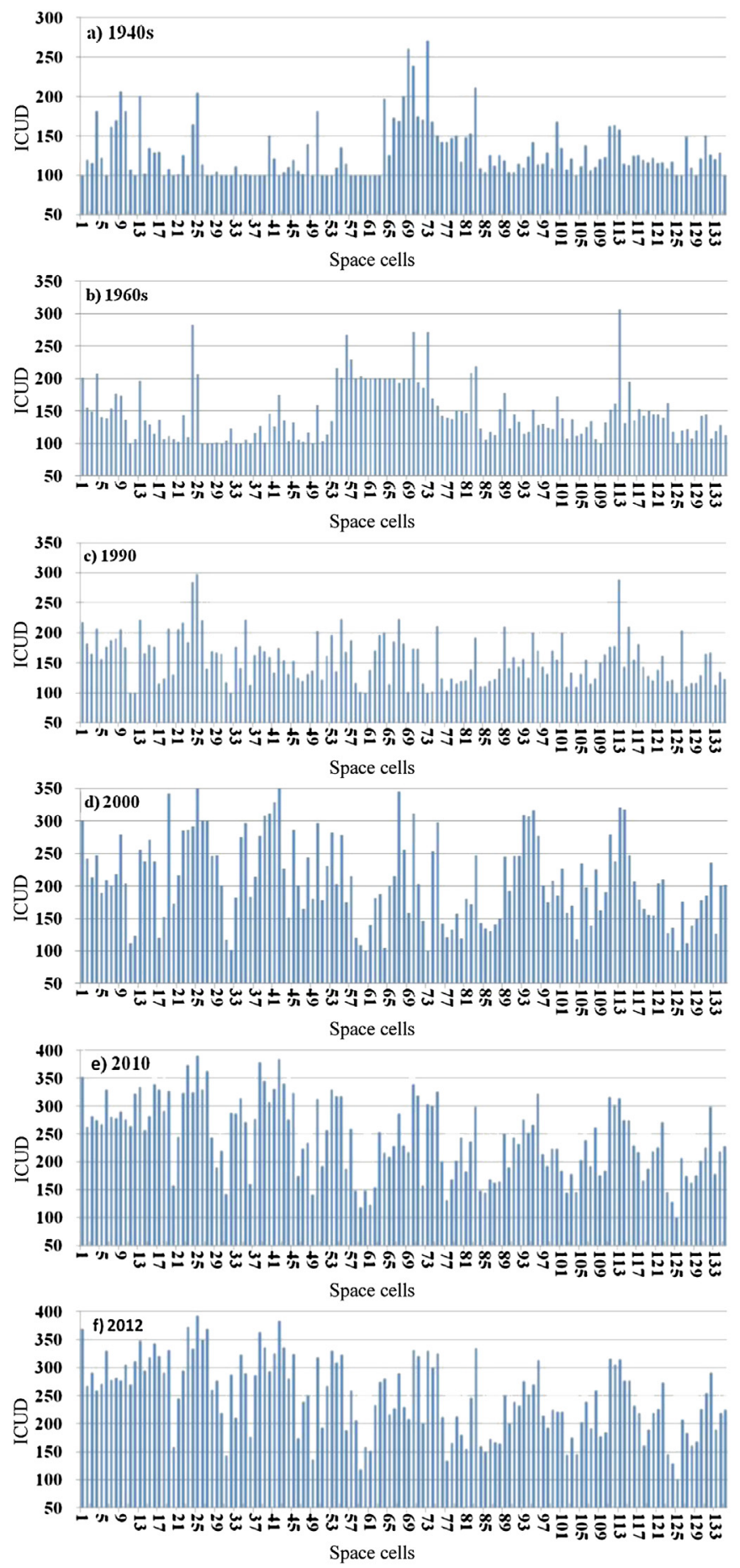

Fig. 4. Temporal variations of ICUD at local scale.

corresponding coastal zones in the geographic space, Wafangdian in Dalian, Yingkou, Tianjin, Shanghai, Cixi and Wenzhou, especially, south of Shanghai and Cixi with values greater than 250, were better developed and utilized. As illustrated in Fig. 4-a, cell 65, which located within Qidong, Jiangsu, divided the whole mainland coastal zone in China into two parts according to the spatial patterns of the values: the values within the southern half fluctuated along shore, and were highlighted within the coastal zone stretched from the Yangtze River estuary to Hangzhou bay; the values within the northern half tended to be small except those carried by Dalian, Yingkou, Tianjin, Yantai and Qingdao, which

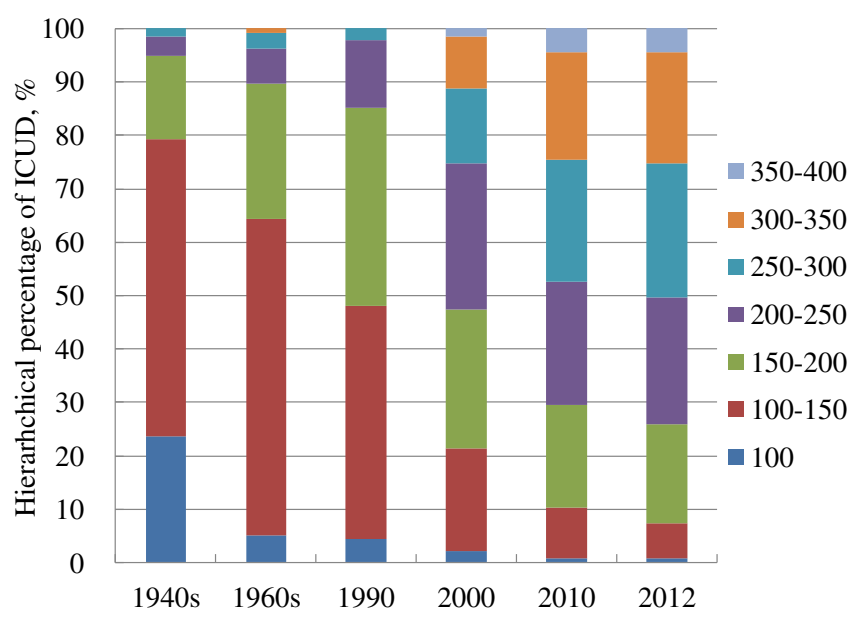

Fig. 5. Structural characters of various levels of ICUD in six time instants.

means, the utilization degree of the southern coastline exhibiting an undulating spatial pattern, and peaked at the Yangtze River estuary and Hangzhou bay, while the utilization degree of the northern part was generally lower.

In 1960s, cells in which the whole coastline remained natural, accounted for $5.18 \%$ of the total number; the coastal area of Donggang, Dalian, Tianjin, Lianyungang, Yancheng, Shanghai, Cixi, Wenzhou and Zhuhai were better developed and utilized, and specifically, the coastline utilization degree of Zhuhai were the highest. As illustrated in Fig. 4-b, the utilization degree of coastline, belonging to cells indexed from 53 to 73 corresponding to coastal area stretched from Lianyungang of Jiangsu to Cixi of Zhejiang where coastline were mainly used for seawall in 1960s, were similar and highlighted.

In 1990, cells in which the whole coastline remained natural, accounted for $4.44 \%$ of the total number; the coastlines in $14.81 \%$ percent of the total cells were better developed and utilized, and the highest utilization degree occurred at the coastal area of Tianjin and Zhuhai. As illustrated in Fig. 4-c: the differences in the coastline utilization degree between the south and the north almost disappeared, exhibiting a geometrical morphology of continuous fluctuation along shore and peaked at Dalian, Tianjin, Yantai, Qingdao, the Yangtze River estuary and the Pearl River Estuary.

In 2000, cells in which the whole coastline remained natural, accounted for $2.22 \%$ of the total number; among the 34 cells in which the coastlines were better developed and utilized, 21 cells located in the north of Jiangsu while the others distributed in Haizhou bay, the Yangtze River estuary, Hangzhou bay, mainland side of Taiwan Strait, the Peal River estuary; the highest coastline utilization degree lied in the coastal zone of Tianjin with the value of 353.84. Similarly, as illustrated in Fig. 4-d: differences of coastline utilization degree in undulating pattern along shore between the north and the south was small, and peak values occurred at Donggang, Tianjin, Yantai, the Yangtze River estuary, Xiamen and the Pear River estuary.

In 2010, only one cell in which the whole coastline remained natural was left; among the 33 cells in which the coastlines were better developed and utilized, 13 cells located in the coastal area of Rongcheng, Jiaozhou bay, Haizhou bay, Hangzhou bay, Xiamen and the Pearl River delta while the others located the coastal areas of circum Bohai Sea; compared to 2000, the highest coastline utilization degree lied in the coastal zone of Tianjin likewise, but with a higher value of 390.16. As illustrated in Fig. 4-e: the area with the better developed and utilized coastline centralized in the coastal area of circum Bohai Sea.

In 2012, only one cell, the same one as in 2000, in which the whole coastline remained natural was left; and the cells with higher and the 
highest coastline utilization degree were the same ones as in 2010, as well as the spatial pattern of ICUD as illustrated in Fig. 4-f.

\section{Discussions}

Spatial-temporal variations of mainland coastline utilization degree over the nearly 70 years were restricted by physical environmental conditions, and principally driven by geographical advantages, policies and social-economic factors. Large estuary deltas and strand plains with flat topography and favorable location conditions were the superior areas for population aggregation and social-economic development, therefore, coastline development and utilization mainly originated in and expanded outwards from these areas.

In 1940s, social-economic development of coastal areas was, overall, in a low level that was not comparable to that in the late 20th century and the early 21st century, and activities of coastline development and utilization concentrated in a few estuary deltas and coastal plains that held large and medium-sized cities. At the beginning of New China, there were a thousand things to be done, however, the household registration system constrained population migration (Cai et al., 2012), additionally, politics, social ideology, tense relationship between mainland and Taiwan, and tense surrounding international political situations at that time had profoundly restricted the social-economic development in coastal area, consequently, coastline development and utilization had changed vey limitedly and mainly appeared in the form of coast defense developing and dike building in some coastal areas (Liu et al., 2012).

The Chinese government determined to reform the economic system in 1978. Five special economic zones, Shenzhen, Zhuhai, Shantou, Xiamen and Hainan province, were established successively since 1980; fourteen coastal cities, including Dalian, Qinhuangdao, Tianjin, Yantai, Qingdao, Lianyungang, Nantong, Shanghai, Ningbo, Wenzhou, Fuzhou, Guangzhou, Zhanjiang, and Beihai were opened up in 1984; subsequently, after 1985, the Yangtze River estuary, the Pear River estuary, Southern Fujian triangle, Shandong peninsula, Liaodong peninsula, Hebei and Guangxi were developed as economic open zones successively; and eventually, coastal economic open zone came out. Additionally, as Pudong in Shanghai was determined to be developed and opened up in 1990, and some coastal economic zones at national level, like Tianjin Binhai New Area, coastal economic zone of Liaoning, Blue Economic Zone of Shandong peninsula, efficient ecological economic zone of the Yellow River delta, coastal zone of Jiangsu, and so on were implemented in sequential order since 2000 , population migrations were accelerated and large populations gathered to the coastal area, leading to more rapid population urbanization and more intensive expansion of construction land for city and industry (Wang and Shang, 2011), which exacerbated the conflict between the large population and the limited land and then facilitated the advances of sea reclamation. Especially since 2003, sea reclamation booms successively occurred nationwide from south to north at a velocity many times faster than before, consequently, leading to the coastline utilization degree increasing many times faster than that before 1990 and even presenting an accelerated development trend since 2000.

Spatio-temporal features of the coastline utilization degree were also characterized by the regional disparities and phased features of coastal economic-social development. Before 1990s, coastal economic development in the north area overall fell behind that in the south area due to the broad muddy tidal flat and the poor accessibility of northern coast, so its coastline utilization degree was overall low with a relatively simple spatial pattern; on the contrary, coastline utilization degree of the southern part was generally high, however, as the southern coast is mainly composed of rocky coast, a few estuary deltas and coastal plains became the centralized distribution area of population and industries, and that is why the coastline utilization degree exhibited an alternative distribution of high values and low values. After 1990 s, especially since 2000 , the northern coast of mainland China, particularly the coast of Bohai bay stepped into a fast growth stage of economy and society, presenting a 'secondmover' advantage, thus, hotspots of coastline utilization degree started to shift from the southern to the northern. At present, a new round of large-scale sea reclamation has been started, and the projected sea reclamation area that had been approved would add up to 2469.03 square kilometers by 2020 according to relevant information on the central government portal website (http://www.gov.cn/), in consequence, the increase of coastline utilization degree is expected to continue in the future, making the pressures of natural coastline protection progressively increase.

Coastline hardening implies burgeoning urbanization in the coastal area induced by the dramatic economic development. Referencing to the standpoints of the United Nations Expert Group Meeting on population distribution, urbanization, internal migration and development, the subsequent challenges, population growth, resource degradation, and inequality of resource distribution, producing resource scarcity, put a demographic and environmental pressure on government's ability to provide vital services such as housing, clean water, infrastructure and health services. Furthermore, the time lags in management response to these challenges may undermine the overall economic productivity and potentially also the government credibility (Baird, 2009). Improvement of authorities' ability to mitigate the demographic and environmental stress and reduction of lag times in management responses to coastal urban environmental challenges are primary and will require anticipation, greater institutional efficiencies, knowledge creation and a focus on action strategies. ICUD offered a deep insight into the coastal utilization that represent coastal urbanization degree on some extent: the larger the index, the higher the coastal urbanization degree. The ICUD evolution maps at provincial(Appendix 1) and local scale(Appendix 2) were obtained by dividing the values of each epoch at provincial and local scale respectively into very low-, low-, moderate-, high-, and very high-utilization degree categories by quintile classification method according to the ICUD values of 2012 at local scale. The area that were characterized by very high-utilization degree category referred to unsustainable coastal utilization class and may need priority of interventions and remedial measures being able to mitigate the demographic and environmental stresses.

The spatial pattern of the ICUD of each point in time and variations over time offered profound insight into the real spatiotemporal characteristics of coastal utilization degree of Mainland China, this study therefore provided an effective and efficient method for the coastal managers to make informed-decisions on coastal sustainable development and planning. With regard to the improvement, supplement of topographic maps of 1960s and acquisition of remote sensing imageries with higher spatial resolution at shorter time intervals will detail the time series and improve the accuracy of analysis results.

\section{Conclusions}

Based on topographic maps and remote sensing imageries, 6 coastline positions over the nearly 70 years were extracted and classified according to development and utilization condition. Then, the index of coastline utilization degree was constructed and calculated at national, provincial and local scale respectively in order to analyze the spatio-temporal dynamics of mainland coastline utilization degree. The conclusions are as follows:

1) Over the nearly 70 years, the mainland coastline utilization degree in China had a continuous and significant increase, especially during the period of 1990-2000, with the extremely rapid 
coastline artificialization, the proportion of natural coastline decreased continuously. Coastline artificialization boomed in 1990s, and kept going in a rapid speed though slowed down after 2000. The remarkable increase in coastline utilization degree occurred almost all over the whole coastal zone of mainland China, but its spatial pattern exhibited a little bit of complexity, because the development and utilization of coastline merely happened at some hotspot areas at first, and then expanded to the surrounding areas, and finally spread across most coastal areas of mainland. The increase of coastline utilization degree in the north was more significant than that in the south, and therefore, the situation that coastline utilization degree of south was higher than that of north reversed around 1990.

2) Hotspots of coastline development and utilization lied in the area of the Yangtze River delta at first, but since 1990s, the coastline utilization degree of Tianjin city, Hebei province and the Pearl River delta surpassed that of the Yangtze River delta, particularly, since 2000, influenced by the construction of Tianjin Binhai New Area, the coastal development degree of Bohai Bay climbed atop, and with its radiant effects, development of the whole circum Bohai Sea region was accelerated, which made coastline utilization degrees of the four provinces that constitute the circum Bohai Sea region occupy the top four positions, consequently, the circum Bohai Sea region, the Yangtze River delta and the Pearl River delta came into being the mode of tripartite confrontation.

3 ) The index of coastline utilization degree is very effective to detect patterns and processes of impacts of human activities on coastline. In China, over the nearly 70 years, especially in the recent 20 years, mainland coastline was developed at a large scale rapidly and intensively with the dramatically intensive sea reclamation and considerable problems of sharp decrease in the proportion of natural coastline. Up to 2000, coastline changes stepped into a new stage that the artificialization of natural coastlines and the structural upgrading of man-made coastlines through mutual conversion coexisted. Currently, disaster risk keeps rising significantly, the integrated coastal zone management (ICZM) is facing progressively severe stresses, and the coastal zone in China is confronted with increasing challenges brought about by climate change and continuous population and industry aggregation. In such a situation, it is needed urgently to advocate the fundamental philosophy of multifunctional coastal zone, to practice moderate sea reclamation, to slow down the speed and limit the extent of sea reclamation, to explore and implement sea reclamation more orderly, to save and protect the remaining natural coastlines, to restore and compensate for the damaged coastal zone ecosystem and so on.

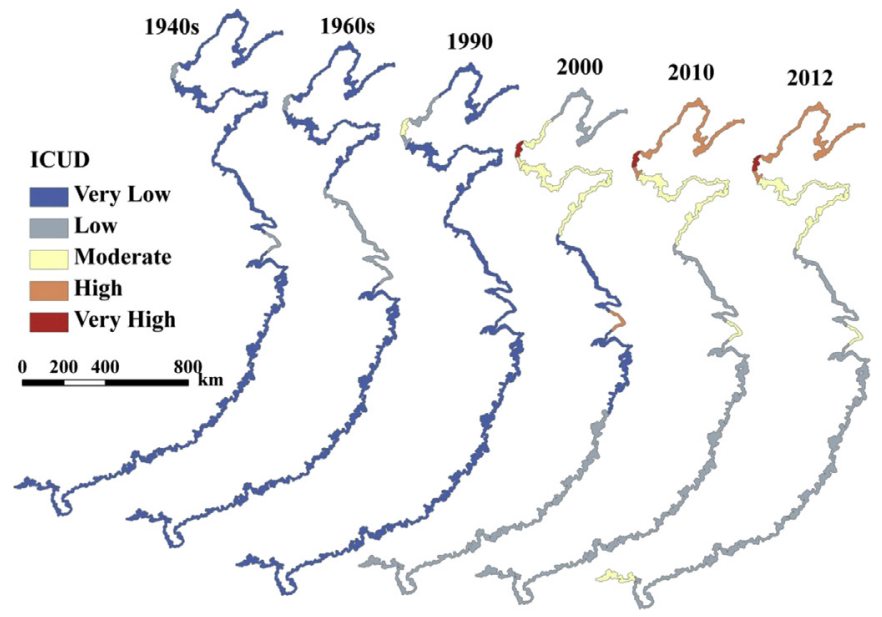

Appendix 1. ICUD evolution at provincial scale.

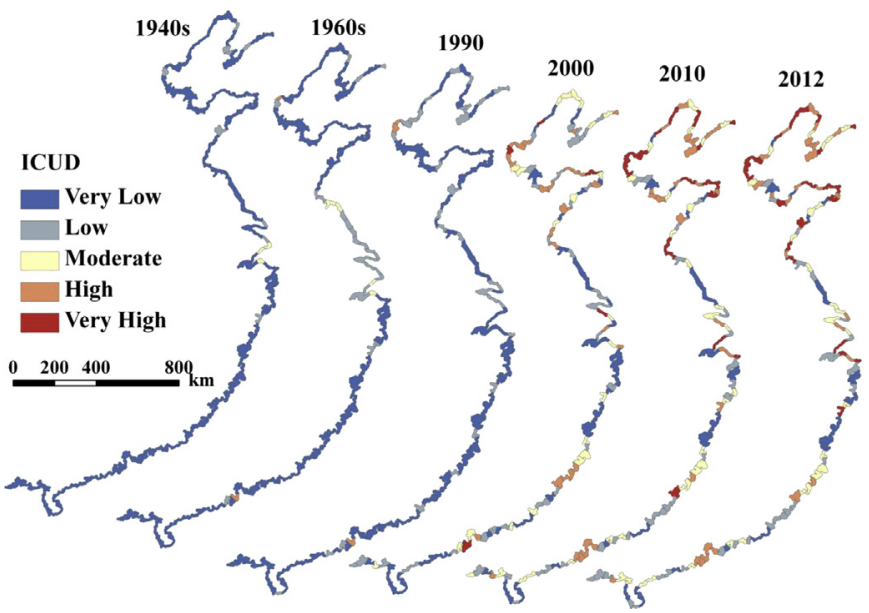

Appendix 2. ICUD evolution at local scale.

\section{Acknowledgment}

This research was funded by the "Strategic Priority Research Program - Climate Change: Carbon Budget and Relevant Issues" of the Chinese Academy of Sciences (No. XDA05130703). Thanks to Wang Yuandong, Wu Li, Di Xianghong, Yu Liangju, Chang Yuanyong and Chen Qing for the contributions they had made during the field surveys, and the processes of data download and processing. Particular thanks to Professor Liu Jiyuan and Professor Xu Xuegong for reviewing the manuscript and giving valuable suggestions.

\section{References}

Ahmad, S.R., Lakhan, V.C., 2012. GIS-based analysis and modeling of coastline Advance and retreat along the coast of Guyana. Mar. Geod. 35, 1-15.

Aiello, A., Canora, F., Pasquariello, G., Spilotro, G., 2013. Coastline variations and coastal dynamics: a space-time data analysis of the Jonian littoral, Italy. Estuar. Coast. Shelf Sci. 129, 124-135.

Baird, R.C., 2009. Coastal urbanization: the challenge of management lag. Manag. Environ. Qual. Int. J. 20, 371-382.

Cai, Y.B., Zhang, H., Pan, W.B., Chen, Y.H., Wang, X.G., 2012. Urban expansion and its influencing factors in natural wetland distribution area in fuzhou city, China. Chin. Geogr. Sci. 22, 568-577.

Crowell, M., Coulton, K., Johnson, C., Westcott, J., Bellomo, D., Edelman, S., Hirsch, E. 2010. An estimate of the U.S. Population living in 100-Year coastal flood hazard areas. J. Coast. Res. 26, 201-211.

Dolan, R., Hayden, B., Heywoode, J., 1978. A new photogrammetric method for determining coastline erosion. Coast. Eng. 2, 21-39.

Durduran, S.S., 2010. Coastline change assessment on water reservoirs located in the Konya Basin Area, Turkey, using multitemporal landsat imagery. Environ. Monit. Assess. 164, 453-461.

Foyle, A.M., Norton, K.P., 2006. Late Holocene nearshore change at a nontida transgressive systems tract strandplain complex, Presque Isle, Pennsylvania, USA. J. Coast. Res. 22, 406-423.

Jackson Jr., C.W., Alexander, C.R., Bush, D.M., 2012. Application of the AMBUR R package for spatio-temporal analysis of coastline change: Jekyll Island, Georgia, USA. Comput. Geosci. 41, 199-207.

Kuleli, T., 2010. Quantitative analysis of coastline changes at the Mediterranean Coast in Turkey. Environ. Monitoring Assessment 167, 387-397.

Kuleli, T., Guneroglu, A., Fevzi, K., Dihkan, M., 2011. Automatic detection of coastline change on coastal Ramsar wetlands of Turkey. Ocean. Eng. 38, 1141-1149.

Kusimi, J.M., Dika, J.L., 2012. Sea erosion at Ada Foah: assessment of impacts and proposed mitigation measures. Nat. Hazards 64, 983-997.

Leatherman, S.P., 1990. Modelling shore response to sea-level rise on sedimentary coasts. Prog. Phys. Geogr. 14, 447-464.

Li, R.X., Liu, J.k, Felus, Y., 2001. Spatial modeling and analysis for coastline change detection and coastal erosion monitoring. Mar. Geod. 24, 1-12.

List, J.H., Farris, A.S., Sullivan, C., 2006. Reversing storm hotspots on sandy beaches: spatial and temporal characteristics. Mar. Geol. 226, 261-279.

Liu, J.Y., Zhang, Q., Hu, Y.F., 2012. Regional differences of China's urban expansion from late 20th to early 21 st century based on remote sensing information. Chin. Geogr. Sci. 22, 1-14.

McNamara, D.E., Murray, A.B., Smith, M.D., 2011. Coastal sustainability depends on how economic and coastline responses to climate change affect each other: Geophys. Res. Lett. 38, L07401. 
Privmavera, J.H., 2006. Overcoming the impacts of aquaculture on the coastal zone. Ocean. Coast. Manag. 49, 531-545.

Quan, S., Kvitek, R.G., Smith, D.P., Griggs, G.B., 2013. Using vessel-based LIDAR to quantify coastal erosion during El Niño and inter-El Niño periods in Monterey Bay, California. J. Coast. Res. 29, 555-565.

Ranasinghe, R., Duong, T.M., Uhlenbrook, S., Roelvink, D., Stive, M., 2013. Climatechange impact assessment for inlet-interrupted coastlines. Nat. Clim. Change 3, 83-87.

Romine, B.M., Fletcher, C.H., 2013. A summary of historical coastline changes on beaches of Kauai, Oahu, and Maui, Hawaii. J. Coast. Res. 29, 605-614.

Sesli, F.A., Karsli, F., Colkesen, I., Akyol, N., 2009. Monitoring the changing position of coastlines using aerial and satellite image data: an example from the eastern coast of Trabzon, Turkey. Environ. Monitoring Assessment 153, 391-403.

Solomon, S.M., 2005. Spatial and temporal variability of coastline change in the Beaufort-Mackenzie region, northwest territories, Canada. Geo Marine Lett. 25, 127-137.

Sridhar, R.S., Elangovan, K., Suresh, P.K., 2009. Long term coastline oscillation and changes of cauvery delta coastline inferred from satellite imageries. J. Indian Soc. Remote Sens. 37, 79-88.

Stockdon, H.F., Asbury, H.S.J., Holman, R.A., Howd, P.A., 2007. A simple model for the spatially-variable coastal response to hurricanes. Mar. Geol. 238, 1-20.

Sun, Y.G., Li, X.Z., Guo, W.Y., He, Y.L., Jia, Y., 2011. Contribution rates of landscape driving factors in coastal reclamation zone based on CLUE-S model validation. Chin. J. Appl. Ecol. 22, 2391-2398 (in Chinese).

Sun, Y.G., Li, X.Z., He, Y.L., Jia, Y., Ma, Z.G., 2010. Spatiotemporal dynamics of land use and land cover changes in different reclamation zones of Yangtze Estuary. Chin. J. Appl. Ecol. 21, 434-441 (in Chinese).
Suo, A.N., Zhang, M.H., Yu, Y.H., Han, F.W., 2012. Loss appraisal on the value of marine ecosystem services of the sea reclamation project for Caofeidian. Mar. Sci. Bull. 36, 108-114 (in Chinese).

Szmytkiewicz, M., Biegowski, J., Kaczmarek, L.M., Okroj, T., Ostrowski, R., Pruszak, Z., Rozynsky, G., Skaja, M., 2000. Coastline changes nearby harbour structures: comparative analysis of one-line models versus field data. Coast. Eng. 40, 119-139.

Twichell, D.C., Flocks, J.G., Pendleton, E.A., Baldwin, W.E., 2013. Geologic controls on regional and local erosion rates of three northern Gulf of Mexico Barrier-Island systems. J. Coast. Res., 32-45.

Vora, K.H., 1987. A note on geophysical explorations for marine archaeology off Tamilnadu Coast, India. Int. J. Naut. Archaeol. 16, 159-164.

Wang, J.J., Shang, Q.M., 2011. The injured coastline. Pearl River Water Transp., 36-40 (in Chinese)

Wang, Y.J., Chen, X.M., Gui, J.D., Huang, T.Y., 2011. The application of soft protection in coastal protection. Jiangsu Constr. 72-74, 91 (in Chinese).

Yates, M.L., Cozannet, G.L., Garcin, M., Salai, E., Walker, P., 2013. Multidecadal Atoll coastline change on Manihi and Manuae, French Polynesia. J. Coast. Res. 29, $870-882$.

Yıldırım, U., Erdoğan, S., Uysal, M., 2010. Changes in the coastline and water level of the Akșehir and Eber Lakes between 1975 and 2009. Water Resour. Manag. 25, 941-962.

Zhang, H.B., Liu, H.Y., Hao, J.F., Li, Y.F., 2012. Spatiotemporal characteristics of landscape change in the coastal wetlands of Yancheng caused by natural processes and human activities. Acta Ecol. Sin. 32, 101-110.

Zhuang, D.F., Liu, J.Y., 1997. Study on the model of regional differentiation of land use degree in China. J. Nat. Resour. 12, 105-111 (in Chinese). 